JOANNA JASTRZĘBSKA

Uniwersytet im. Adama Mickiewicza w Poznaniu

\title{
CZY INTERPRETACYJNA „ZEMSTA" TRWA? ROSJA W POLSKIEJ PROZIE PODRÓŻNICZO-REPORTAŻOWEJ OSTATNICH LAT
}

Koniec XX wieku przyniósł niezwykle ciekawe zjawisko, które bezpośrednio wpłynęło na rozwój nowej humanistyki - nastąpiła zmiana modelu władzy. Do tej pory władza funkcjonowała wertykalnie, piramidalnie, model ten określano jako hierarchiczny. $\mathrm{W}$ ostatniej dekadzie XX wieku, w związku $\mathrm{z}$ rozwojem na wielu płaszczyznach procesów globalizacyjnych, dotychczasowy model został zastąpiony przez horyzontalny model siatki, wyznaczający centra i marginesy ${ }^{1}$.

Przyjmując założenie, które jest mi bardzo bliskie, że literatura stanowi laboratorium społeczne, literacką ilustracją wspomnianych zmian władzy byłby fragment głośnej, skandalizującej książki Izabeli Filipiak Absolutna amnezja, opublikowanej w 1995 roku. Bohaterką jest młoda, nastoletnia dziewczyna, nieodnajdująca się w rzeczywistości, w której żyje. Nieprzystępność otaczającego

${ }^{1}$ E. Domańska, O poznawczym uprzywilejowaniu ofiary, w: H. Gosk, B. Karwowska (red.), (Nie)obecność: pominięcia $i$ przemilczenia $w$ narracjach XX wieku, Dom Wydawniczy Elipsa, Warszawa 2008, s. 22. 
świata odkrywa również w zmianach relacji władzy: „Myślałam, że granice mogą być tylko między państwami, czyli wzdłuż albo w poprzek. [...] Ale granice mogą być też wzwyż, w głąb, a może nawet w inny wymiar"2.

Wspomniana zmiana relacji władzy miała bezpośrednie przełożenie na praktyki naukowe. Nowa humanistyka, zarówno na gruncie światowym, europejskim, jak i polskim otworzyła pole dla nowego paradygmatu naukowego, nowatorskich dyscyplin naukowych, a także praktyk badawczych. Siatka, która powstała, pozwala na współpracę nie tylko między poszczególnymi dyscyplinami, lecz także między techniką (humanistyka cyfrowa), nauką (humanistyka kognitywna) i społeczeństwem (humanistyka zaangażowana).

Na polu naukowym nowa humanistyka dała możliwości stworzenia nurtów badań, które miałyby wieloraką przynależność dyscyplinową. Należą do nich m.in. badania genderowe, badania pamięci, studia afektywne, a także badania postkolonialne. Te ostatnie będą przedmiotem mojego szczególnego zainteresowania w tym artykule. Studia postkolonialne, rozwijające się od lat 80. XX wieku w Europie Zachodniej i Stanach Zjednoczonych dotarły do Polski z opóźnieniem. Gdy przeżywały swój rozkwit na Zachodzie, w krajach Europy Wschodniej odbywał się proces dekonstrukcji systemu opresji władzy, który spełniał wszystkie kryteria procesu dekolonizacyjnego ${ }^{3}$.

Postkolonializm nie był kolejnym etapem tradycyjnej walki antykolonialnej. Był raczej teoretycznym namysłem nad dyskursem kolonialnym. Spektrum zainteresowań badaczy tego nurtu jest szerokie i dotyczy głównie relacji między władzą a kulturą ${ }^{4}$. Nie można jednak przemilczeć politycznego zaangażowania tego rodzaju badań. Zarówno ich twórcy i teoretycy, m.in. Frantz Faron, Edward

\footnotetext{
${ }^{2}$ I. Filipiak, Absolutna amnezja, Wydawnictwo Obserwator, Poznań 1995, s. 101.

${ }^{3}$ Zob. D. Kołodziejczyk, Postkolonialny transfer na Europe Środkowo-Wschodnia, w: R. Nycz (red.), Kultura po przejściach, osoby z przeszłością. Polski dyskurs postzależnościowy - konteksty i perspektywy badawcze, t. 1, Seria Wydawnicza Centrum Badania Dyskursów Postzależnościowych, Kraków 2011, s. 117-136.

${ }^{4}$ E. Domańska, Badania postkolonialne, w: L. Gandhi, Teoria postkolonialna: wprowadzenie krytyczne, przeł. J. Serwański, Wydawnictwo Poznańskie, Poznań 2008, s. 158.
} 
Said, Gayatri Chakravorty Spivak, jak i same źródła badań, powiązane były z założeniami lewicowej myśli politycznej, a na polu naukowym z dekonstrukcją, poststrukturalizmem oraz marksizmem. Kolejnym elementem, który należy podkreślić w kontekście badań postkolonialnych, jest ich zróżnicowanie. Nie mam tu na myśli zróżnicowania zachodnich czy też amerykańskich dyskursów postkolonialnych, lecz pluralizm, który pojawił się w drugiej połowie lat 90. XX i dotyczył Europy Środkowej i Wschodniej. Studia te nie wszędzie spotkały się z żywym zainteresowaniem. Problematyka ta dłużej rozwijała się w Czechach i na Węgrzech. Znacznie szybciej studia postkolonialne zaczęto wykorzystywać w Estonii, na Litwie czy też w Polsces.

Jeśli spojrzymy na sytuację literatury polskiej po 1989 roku przez pryzmat rozpoznań badań postkolonialnych, możemy wysunąć ciekawe wnioski. Sytuacja dominacji politycznej Rosji nie była do tej pory przedmiotem zainteresowania ani badaczy zachodnioeuropejskich, ani amerykańskich. Jednak aby wykorzystać założenia studiów postkolonialnych, niezbędne jest dostosowanie instrumentów tych badań do polskich realiów. Na początek warto zwrócić uwagę na szczególne warunki, które ukształtowały nowoczesne polskie społeczeństwo od XIX wieku. Sytuacja zaborowego zniewolenia, dwóch wojen światowych i niepełnej suwerenności po 1945 (z przerwą w latach 1918-1939) sprawiły, że tożsamość kształtowała się między opresją, zagrożeniem, uzależnieniem i uciskiem. Sytuacja ta nie mogła pozostać bez znaczenia w procesie kształtowania zbiorowej tożsamości, a narracje ją tworzące były (i nadal są) przekazywane z pokolenia na pokolenie.

Dopasowania instrumentarium badań postkolonialnych do sytuacji polskiej literatury dokonała Hanna Gosk ${ }^{6}$. Należy jednak zaznaczyć, że polskie realia nie były nigdy stricte kolonizatorskie ani kolonialne, tak jak określa się to w kontekście działań na przykład

${ }^{5}$ B. Bakuła, Studia postkolonialne w Europie Środkowej oraz Wschodniej 19892009. Kwerenda wybranych problemów badawczych, w: R. Nycz (red.), Kultura po przejściach, osoby z przeszłością..., s. 138.

${ }^{6} \mathrm{H}$. Gosk, Polskie opowieści w dyskurs postkolonialny ujęte, w: tejże, B. Karwowska (red.), (Nie)obecność. Pominięcia i przemilczenia..., s. 75-88. 
imperium brytyjskiego. Z tej konstatacji wynika również zaproponowany przez warszawską literaturoznawczynię podział. Zakładając, że sytuacją postkolonialną nie można nazwać rzeczywistości polskiej w dwudziestoleciu międzywojennym oraz po roku 1989, Hanna Gosk proponuje inne termin: w pierwszym wypadku - sytuacja post-zaborowa, w drugim sytuacja post-zależnościowa ${ }^{7}$. Gosk zauważa ponadto, że specyfika polskiej sytuacji polega na różnorodności i wielości sytuacji zależności, a każda z nich wypracowała własny dyskurs ${ }^{8}$. Do czasów zaborów Rzeczpospolita szlachecka, zdaniem Gosk, odgrywała rolę imperialną, kolonizując nie tylko sąsiadów (tworząc peryferie), lecz również inne klasy społeczne 9 . Okres zaborów to czas opresji, Międzywojnie natomiast to wariant mieszany - sytuacja post-zaborowa i imperialna (np. wobec Kresów Wschodnich). Druga wojna światowa to czas ponownej opresji ze strony zaborcy, a sytuacja od 1945 do 1989 to czas niepełnej suwerenności. Wreszcie, najbardziej mnie interesujące, uwarunkowania po 1989 roku, określane jako sytuacja postzależnościowa. Jest ona interesująca, ponieważ mieszają się w niej pamięć zarówno roli ofiary, jak i roli opresora, czego dowodem będzie prezentowana przeze mnie analiza utworów literackich. Należy w tym miejscu dodać, że przytoczona przeze mnie klasyfikacja nie jest jedyną istniejącą $w$ polskich badaniach literaturoznawczych, wykorzystujących badania postkolonialne. Zagadnieniem tym zajmowali się również inni znamienici literaturoznawcy ${ }^{10}$, dla mnie

\footnotetext{
${ }^{7}$ Tamże, s. 75 . W późniejszych opracowaniach terminy te zapisywane były już bez dywizu, dlatego też w dalszej części tekstu stosować będę zapis bez dywizu.

${ }^{8}$ Tamże, s. 76.

${ }^{9}$ Myśl tę rozwinął i opracował szerzej Jan Sowa w książce Fantomowe ciało króla: peryferyjne zmagania z nowoczesną formą, Universitas, Kraków 2011.

${ }^{10}$ Między innymi: C. Cavanagh, Postkolonialna Polska. Biała plama na mapie współczesnej teorii, przeł. T. Kunz, „Teksty Drugie” 2003, nr 2-3; A. Fiut, Polonizacja? Kolonizacja?, „Teksty Drugie” 2003, nr 6; W. Bolecki, Myśli różne o postkolonializmie. Wstęp do tekstów nie napisanych, „Teksty Drugie” 2007, nr 4; G. Borkowska, Polskie doświadczenie kolonialne, „Teksty Drugie” 2007, nr 4; D. Skórczewski, Polska skolonizowana, Polska zorientalizowana. Teoria postkolonialna wobec „innej Europy”, „Porównania” 2009, nr 6; K. Chmielewska, Tak i nie. Meandry polskiego dyskursu postkolonialnego i postzależnościowego,
} 
natomiast kategorie zaproponowane przez Hannę Gosk są najbardziej operatywne.

W kontekście przytoczonych rozpoznań warto zwrócić uwagę na pozycje i rolę polskich narracji dotyczących Rosji w literaturze po 1989 roku. Sytuację odwrotną, czyli kolonialnej ekspansji Rosji, opisała Ewa Thompson w książce Trubadurzy imperium. Literatura rosyjska i kolonializm ${ }^{11}$. Z kolei temat dotyczący postzależnościowych relacji między Polską a Rosją nie był do tej pory tematem intrygującym badaczy postkolonializmu. Jako jedna z pierwszych zajęła się nim Maria Janion w książce Niesamowita Słowiańszczyzna: fantazmaty literatury ${ }^{12}$, w której odnotowała nierówne relacje w polskich literackich opisach Rosji. Badaczka przywołała bardzo ważne dla moich rozważań studium Maxima Waldsteina, który w duchu koncepcji Edwarda Saida omówił kanoniczne dla polskiej literatury Imperium Ryszarda Kapuścińskiego ${ }^{13}$. Rozpoznania te wyznaczyły w polskim literaturoznawstwie nowe perspektywy poznawcze, które polegały na poszukiwaniu (śladów) orientalizmu w utworach dotyczących Rosji. Rozpoznania te kontynuuje również w ostatnich latach Hanna Gosk, która opracowała dwie książki dotyczące postzależnościowych wątków w literaturze polskiej XX i XXI wieku ${ }^{14}$.

w: H. Gosk, E. Kraskowska (red.), (P)o zaborach, (p)o wojnie, ( $p$ )o PRL. Polski dyskurs postzależnościowy dawniej $i$ dziś, t. 3, Seria Wydawnicza Centrum Badania Dyskursów Postzależnościowych, Kraków 2013, s. 563-564.

${ }^{11}$ E. Thompson: Trubadurzy imperium. Literatura rosyjska i kolonializm, przeł. A. Sierszulska, Universitas, Kraków 2000.

${ }^{12}$ M. Janion, Niesamowita Słowiańszczyzna: fantazmaty literatury, Wydawnictwo Literackie, Kraków 2006. Mam tu na myśli szczególnie rozdział Polskie i ruskie.

${ }^{13}$ M. Waldstein, Observing Imperium: A Postcolonial Reading of Ryszard Kapuscinski's Account of Soviet and Post-Soviet Russia, „Social Identities” 2002, t. 8 , nr 3, s. 481-499.

${ }^{14} \mathrm{H}$. Gosk, Opowieści „Skolonizowanego/kolonizatora”: w kręgu studiów postzależnościowych nad literatura polska XX i XXI wieku, Universitas, Kraków 2009 (tu szczególnie rozdział Głosy byłych subalternów. O postzależnościowych aspektach polskiej prozy współczesnej, s. 197-230) oraz tejże, Wychodzenie $z$ „cienia imperium”: wątki postzależnościowe w literaturze polskiej XX i XXI wieku, Universitas, Kraków 2015 (tu szczególnie rozdział Konstruowanie 
Przedmiotem mojego zainteresowania są sposoby przedstawiania Rosji i byłych republik radzieckich w najnowszych polskich opowieściach podróżniczo-reportażowych. Warto zwrócić na to zagadnienie uwagę, ponieważ lawinowo wzrosła w ostatnich latach popularność książek o tej tematyce. Od 1989 roku przybywa relacji z podróży do Rosji. Jej autorami są nie tylko dziennikarze (Jacek Hugo Bader, Maciej Jastrzębski, Wojciech Jagielski, Paweł Reszka), lecz także naukowcy (Jędrzej Morawiecki, Bartosz Jastrzębski, Andrzej Dybczak) oraz podróżnicy i przewodnicy (Wojciech Śmieja, Tomasz Grzywaczewski). Mój artykuł stanowi kontynuacje rozważań podjętych w tekście Polski „Orient”? Reporterskie (re)wizje Rosji po rozpadzie imperium ${ }^{15}$. Zaproponowałam w nim następującą klasyfikację Polaków piszących o Rosji: osadnik (Mariusz Wilk), rekolonizator (Krystyna Kurczab-Redlich) i wędrowiec (Jacek Hugo-Bader). W niniejszej pracy chciałabym sprawdzić, uwzględniając rosnącą popularność publikacji dotyczących Rosji, czy zaproponowana przeze mnie wcześniej klasyfikacja, wciąż jest aktualna, jak ewentualnie ewoluowała i czy zmienił się sposób pisania o Rosji i Rosjanach. Zależy mi na zbadaniu, w jaki sposób przesunęły się akcenty zainteresowań polskich reportażystów oraz podróżników i jak te relacje wpływają na kształtowanie obrazu Rosji i Rosjan w świadomości czytelnika. Artykuł ten poświecę trzem książkom: Crème de la Kreml: 172 opowieści o Rosji Wacława Radziwinowicza, Po Bajkale: rowerem przez Syberie Jakuba Rybickiego oraz Jakuck: słownik miejsca Michała Książka.

\section{KURA — NIE PTICA, CZYLI ROSJA — ZAGRANICA}

Wacław Radziwinowicz to znany zarówno w Polsce, jak i w Rosji korespondent „Gazety Wyborczej”. Relacjonował, głównie z Mo-

psychospołecznej przestrzeni sąsiada. Niemiecki Zachód i rosyjski Wschód w reportażowo-podróżniczej prosie polskiej ostatnich lat, s. 215-236).

${ }^{15}$ J. Jastrzębska, Polski „Orient”? Reporterskie (re)wizje Rosji po rozpadzie imperium, w: tejże (red.), Mapy świata, mapy ciała: geografia i cielesność w literaturze, Wydawnictwo Libron - Filip Lohner, Kraków 2014, s. 235-252. 
skwy, rosyjskie wydarzenia od 1997 roku. W grudniu 2015 roku władze Federacji Rosyjskiej cofnęły mu akredytację dziennikarską i nakazały opuścić kraj. Korespondent jest autorem trzech książek o Rosji: Gogol w czasach Googléa: korespondencje z Rosji 1998-2012 (Agora, Warszawa 2013), Soczi: igrzyska Putina (Agora, Warszawa 2014) oraz Crème de la Kreml. 172 opowieści o Rosji (Agora, Warszawa 2016). Najnowsza książka Radziwinowicza to kontynuacja nominowanego do nagrody Nike pierwszego zbioru felietonów publikowanych w „Gazecie Wyborczej”. Ostania publikacja zawiera artykuły $\mathrm{z}$ lat 2012-2016.

Wacław Radziwinowicz na kilku płaszczyznach opowieści o Rosji kontynuuje rekolonizatorski ton, który zapoczątkowała Krystyna Kurczab-Redlich w swoich reportażach. Już we wstępie, napisanym tuż po wyjeździe z Rosji, w lutym 2016 roku, Radziwinowicz deklaruje, że jego związki z Rosja trwają od pokoleń. Wszystko zaczęło się od historii babci Anny i jej męża, którzy w latach 20. XX wieku uciekli z Barnaułu „od bolszewików”. Mitem założycielskim historii rodziny jest więc narracja o ucieczce z rzeczywistości, w której „[...] bolszewicy nocami zabierali 'białych' na dworzec w Barnaule, a potem miasto truchlało, słysząc ludzi żywcem palonych w piecach parowozów"16. Autor, otwierając swój tom przytoczoną historią, utwierdza czytelnika w przekonaniu, że ma prawo opisywać Rosję, ponieważ w pewnym stopniu już jej doświadczył - zna ją z przekazów rodzinnych, obcował z nią na co dzień: „Mieszkaliśmy w Olsztynie. [...] I ciągle wracały opowieści o tym, co w $1945 \mathrm{r}$. wyrabiali tu czerwonoarmiści, jak to określił Stalin, 'zabawiając się z kobietami”" (CK, s. 6). Ponadto autor zalicza się do grupy „białych", potomków zesłańców syberyjskich, innych na obcej ziemi.

$\mathrm{Na}$ tę historię rodzinną nałożony jest inny, magiczny i nie do końca jasny sentyment. Radziwinowicz przytacza anegdotę o tym, jak zabrał siedemdziesięcioletnią babcię nad polskie wybrzeże, by pokazać jej po raz pierwszy morze. Gdy wskazał, że za Mierzeją Wiślaną znajduje się Rosja, „[...] Anna skamieniała. Do zachodu

\footnotetext{
${ }^{16}$ W. Radziwinowicz, Crème de la Kreml: 172 opowieści o Rosji, Agora, Warszawa 2016, s. 6. Kolejne cytaty lokalizuję w tekście za tym wydaniem, podając w nawiasie skrót CK i numer strony.
} 
słońca bez ruchu siedziała na pisaku, patrząc tam - na prawo. Nie chciała ani jeść, ani pić, nie marzła. Tylko patrzyła. Przez łzy" (CK, s. 7).

W najnowszej książce Radziwinowicza mamy więc do czynienia z dwiema Rosjami: „magiczną” i „zwyczajną". Podział ten zdaje się już klarować we wstępie sam autor, a kontynuuje go w 172 reportażach. „Ta zwyczajna, niestołeczna Rosja jest przygnębiająco szarobetonowa. Jeszcze gorsze wrażenie robi tam, gdzie zimno, bo silne mrozy i wilgoć barwią beton wielkiej płyty na brunatno" (CK, s. 7). Druga twarz Rosji - magiczna, istnieje na dalekich krańcach, $\mathrm{w}$ „ponadstuletnim drewnianym domu w Krasnojarsku. $\mathrm{Z}$ zewnątrz rudera, za to $\mathrm{w}$ środku zaskakujące ciepło uśmiechów, miłej rozmowy, ciepła bijącego $\mathrm{z}$ wielkiego białego pieca - takiego, na jakim się śpi. Żaden kaloryfer nie da takiego poczucia przytulności" (CK, s. 7). Krasnojarska chata staje się więc synekdochą peryferii, przeciwstawioną imperialnemu centrum, czyli Moskwie, która "jest za duża, zbyt bogata” (CK, s. 8). Ten binarny podział Rosji przełamany zostaje jednak przez dostrzeżenie w Rosjanach czegoś, czego sklasyfikować Radziwinowicz nie potrafi. To właśnie oni zmieniają oblicze stolicy kraju. Spotkanie z „'inteligencją’, ludźmi o wielkiej wiedzy i ciętym poczuciu humoru" (CK, s. 8) - jak ich określa Radziwinowicz - to dla Polaka „wspaniała przygoda”.

Wstęp do książki jest doskonałą ilustracją tego, co odnajdziemy w pozostałej jej części. Ułożone chronologicznie reportaże (felietony) zbudowane są w niemal ten sam sposób. Tytuł każdej części odpowiada schematowi: $\mathrm{X}$, czyli $\mathrm{Y}, \mathrm{np}$. Rosja, czyli pieróg z niespodzianka, Pozdrowienia $z$ Krymu, czyli „soviet dream”, Monstrancja, czyli goła kobieta zjadła mózg pudla. Już sama konstrukcja tytułu sugeruje, że autor będzie czytelnikowi wyjaśniał, co jest czym w Rosji. Na taką interpretację naprowadza powtarzany spójnik „czyli”, który nie tylko wyjaśnia, lecz także poszerza znaczenie. Oczywiście jest to zabieg celowy i wielokrotnie wprowadzający czytelnika w konsternację. Dopiero lektura całego felietonu wyjaśnia, co miał oznaczać tytuł. Należy tu zaznaczyć, że Radziwinowicz umiejętnie rozgrywa napięcie między tytułem a treścią, rozbudzając w czytelniku ciekawość. 
Podobnie schemat można wyznaczyć w budowie każdego z felietonów. Wstęp jest nawiązaniem do sytuacji społeczno-politycznej w Rosji bądź też cytatem ze źródła, ale ad rem Radziwinowicz przechodzi zwykle dopiero w kolejnych akapitach. Następne elementy układu to: rozwinięcie tematu, dygresja, a na koniec - ironiczna puenta. Schemat ten $\mathrm{z}$ jednej strony dowodzi kunsztu dziennikarskiego Radziwinowicza, ponieważ wypracował go samodzielnie przez lata doskonaląc warsztat. Z drugiej strony jednak ciągłe powielanie modelu oznacza brak otwartości na nowe sposoby opisu rzeczywistości Rosji.

Tematyczne zainteresowania polskiego korespondenta oscylują wokół spraw związanych z polityką i problemami społecznymi Rosji, takimi jak alkoholizm czy przestępczość. W związku z tym, że chronologiczny porządek książki przypada na lata agresji Rosji na Ukrainę, część tekstów poświęcona jest również tym kwestiom. Na tym poziomie Wacław Radziwinowicz niestety nie wykracza poza utarte szlaki opisu Rosji. Wydaje się, że zbiór felietonów (zarówno ten, jak i poprzedni) kontynuują ścieżkę wyznaczoną przez Barbarę Kurczab-Redlich. Radziwinowicz jako „biały” przybysz z Zachodu ostro komentuje politykę prowadzoną przez Rosjan, pozwalając sobie na ocenę zarówno sytuacji politycznej, jak i działalności poszczególnych organów państwa (np. Udany produkt, czyli kariera człowieka sowieckiego; CK, s. 146-150). Nie robi tego jednak tak ostentacyjnie, jak Krystyna Kurczab-Redlich, która oskarżała rosyjskie społeczeństwo, pisząc: „Największy 'deficyt' narodu rosyjskiego to świadomość społeczna. Śladu tego, co Polaków mobilizowało w Poznaniu, Radomiu, Lublinie, Kielcach, Szczecinie i Gdańsku"17.

W książce można odnaleźć również elementy, które sugerują, że Rosjanie nie mają swoich wzorów - ani politycznych, ani kulturowych. Przykładem może być opis stolicy Federacji, gdzie znajduje się park Gorkiego, który „jest jak przeniesiony z jakiegoś Amsterdamu czy innej Brukseli” (CK, s. 89).

Radziwinowicz nie dopuszcza do głosu Rosjan. Wprawdzie wykorzystuje bardzo często wypowiedzi polityków czy też naukowców,

${ }^{17}$ K. Kurczab-Redlich, Pandrioszka, Dom Wydawniczy REBIS, Poznań 2011, s. 77. 
cytuje wyniki badań, lecz robi to instrumentalnie - podporządkowuje je pod krytykę Rosji. By przybliżyć polskiemu czytelnikowi rosyjską rzeczywistość, korespondent często w swoje historie wplata polskie wątki. Wówczas pojawia się postzależnościowa opozycja my-oni. Przy opisie wykorzystywania Syberii jako nieskończonego źródła zasobów naturalnych (a co za tym idzie sposobu finansowania skarbu państwa), pisze: „My też to dobrze znamy, bo i nas Syberia zdrowo przez ponad półtora stulecia drenowała i wielu wybitnych Polaków, zamiast trudzić się u podstaw na swoim, poszło pod konwojem badać i zagospodarowywać Kamczatkę czy Brzegi Bajkału” (CK, s. 117). Próbuje również znaleźć odpowiedniki opisywanych sytuacji w polskim życiu publicznym. Historię kleryka i wykładowcy, który po publicznej krytyce cerkwi został wyrzucony z Moskiewskiej Akademii Duchowej, porównuje z działalnością księdza Lemańskiego (Zakała cerkwi, czyli rosyjski ksiądz Lemański; CK, s. 135-136). Podobny zabieg stosuje, opisując perypetie filmu Popiół, który opowiada o „deportacjach” mieszkańców Kaukazu na Syberię i do Kazachstanu w 1944 roku. Zamieszanie związane z premierą filmu porównuje do sytuacji polskiego filmu Katyń, nazywając Popiół czeczeńskim Katyniem.

Oryginalne jest natomiast zwrócenie uwagi przez Radziwinowicza na język. Wśród felietonów pojawiają się bardzo ciekawe teksty o zmianach, które zachodzą we współczesnym języku rosyjskim: o jego wulgaryzacji, wprowadzeniu do codziennego obiegu słów z żargonu więziennego i o działaniach rządowych, których celem jest dbanie o poprawność językową. Choć i przy tej kwestii szyderczo ironizuje o projekcie ustawy ministra Medinskiego. W myśl nowej ustawy zakazane będzie używanie słów zapożyczonych z języków obcych, co polski korespondent puentuje następująco: „A przecież słowo 'minister' nie wyrasta z korzeni rosyjskich. Sam Medinski nie miałby pewnie nic przeciwko nadaniu mu starobolszewickiego tytułu 'ludowego komisarza do spraw kultury', ale 'komisarz' i 'kultura' też rdzennie rosyjskie nie są” (CK, s. 173).

Wacław Radziwinowicz na kilku poziomach narracji kontynuuje rekolonizatorski sposób pisania o Rosji, który rozpoczęła już Krystyna Kurczab-Redluich. Robi to jednak w sposób znacznie bardziej 
ostrożny. Stara się nie wywyższać historii Polaków, nie poucza Rosjan. Tym, co szczególnie wyróżnia jego felietony jest ironia. Pozwala sobie zastosować ten zabieg, ponieważ zalicza się, jak we wstępie zaznaczył, do „białych”, lepszych, znających Rosję. Choć dostrzega wśród Rosjan ludzi, od których mógłby czerpać wiedzę, by zrozumieć ten kraj, nie dopuszcza ich do głosu. Polski dziennikarz opowiada o tej rzeczywistości tak, jakby przynależał do zupełnie innego świata, do Zachodu. Dla członków tej wspólnoty wszystko, co rosyjskie wydaje się absurdalne, stąd ironia, która staje się jedynym narzędziem opisu. Figura ta, stanowiąca bardzo często element parodii, wyraźnie wskazuje na poczucie wyższości wobec opisywanej przestrzeni.

Czytelnik, który sięga po książkę Radziwinowicza, uśmiechnie się do siebie w wielu momentach, nie skończy jednak lektury z poczuciem, że zrozumiał choć odrobinę Rosjan i ich rzeczywistość.

\section{„NU, POJECHALI"}

Jakub Rybicki, socjolog, dziennikarz i podróżnik ${ }^{18}$, z zamiłowania fotograf, zadebiutował w 2015 roku książką Po Bajkale: rowerem przez Syberię. Książka jest relacją z dwóch rowerowych wypraw po Rosji. Pierwsza odbyła się w 2008 roku. Wówczas Rybicki, student filologii wschodniosłowiańskiej, w czasie pobytu na stypendium w Irkucku przemierzył trasę z Ułan Ude do Ułan Bator. Po pięciu latach powrócił do Rosji i wspólnie z przyjacielem przejechał rowerem po zamarzniętym Bajkale. Ta relacja $\mathrm{z}$ podróży doskonale wpisuje się w nurt turystycznych opowieści o Rosji i Rosjanach. Rybicki, podobnie jak Jacek Hugo-Bader w Białej goraczce ${ }^{19}$, przyjmuje rolę wędrowca. Wyznacza sobie punkt startowy i miejsce docelowe, rzucając się w wir przygód związanych z ekstremalną podróżą i spotkanymi na drodze ludźmi.

Podobnie jak znaczna część reportażystów opowiadających o Rosji, również Rybicki rozpoczyna swoją narrację od deklaratywnego

${ }^{18}$ Jakub Rybicki prowadzi bloga, na którym na bieżąco relacjonuje swoje podróże, http://www.jakubrybicki.pl/ (20.04.2016).

${ }^{19}$ J. Hugo-Bader, Biała gorączka, Wydawnictwo Czarne, Wołowiec 2009. 
wstępu. Wyrzeka się cytatów z Tiutczewa i mott typu: „Rosja to nie kraj, Rosja to stan umysłu”. Jednak już na pierwszych stronach pisze:

Nie będę się starał Rosji zrozumieć, bo naszą wspaniałą, europejską logikę możemy spokojnie zostawić w depozycie u celnika na przejściu granicznym w Bezledach. Nie przyda się na wiele w zderzeniu z rosyjskim żywiołem. Nie będę też pisał wiele o Putinie, biedzie, syfie, wojnie, korupcji i pijaństwie, choć to oczywiście bardzo wdzięczne tematy. Można tym poczytać w każdej innej poświęconej Rosji książce ${ }^{20}$.

Ambicją Rybickiego jest stworzenie „historyjek” (jak sam je określa) o kraju, w którym nie tylko oligarchom powodzi się dobrze. Chciałby przedstawić wizerunki ludzi, którzy potrafią „cieszyć się życiem tak, jak nikt inny” (PB, s. 6), mają znacznie więcej wolności niż Europejczycy, żyją otoczeni zniewalająco piękną przyrodą. Podobnie jak Radziwinowicz, Rybicki wspomina o magii, dzięki której mieszkańcy Syberii wchodzą w relacje z przyrodą. Ponadto pisze, że chce skupić się na „ludziach i dziwach”, które spotkał na swojej drodze. Mimo wielu obiecujących początkowych deklaracji nowatorskiego podejścia do opisu Rosji, za chwile Rybicki dodaje:

A jest się czemu dziwować. Rosja sama w sobie jest osobliwa, zaskakując, niezrozumiała, nawet magiczna. Na Syberii wszystkie epitety trzeba podnieść do kwadratu, a Bajkał - fenomen na skalę światową - to prawdziwe jądro mistyki i tajemnych sił, które oddziałują na wszystkich, którzy się z nim zetknęli. Jeśli po lekturze zrozumiecie odrobinę więcej — to świetnie. Jeśli nie — jeszcze lepiej (PB, s. 7).

Pierwsza część książki, zatytułowana Step rozpoczyna się od opisu Irkucka, uznawanego przez autora za stolicę Syberii, „krainy, która w Polsce kojarzona jest przede wszystkim ze zsyłkami, bydlęcymi wagonami, gułagiem, brzękiem łańcucha na umęczonych polskich nogach, straszliwymi mrozami i ogólną niedolą" (PB, s. 9). Rybicki natomiast pisze, że „na złość” zakochał się „w irkuckim syfie”. To, co najbardziej przyciąga uwagę podróżnika to miejscowe kobiety. Jest

${ }^{20}$ J. Rybicki, Po Bajkale: rowerem przez Syberię, Wydawnictwo Świat Książki, Warszawa 2015, s. 5-6. Kolejne cytaty lokalizuję w tekście za tym wydaniem, podając w nawiasie skrót PB i numer strony. 
zaciekawiony zarówno ich „nietypowym” ubiorem, czyli niedostosowanym do pory roku i temperatury, co ich ambicjami i planami małżeńskimi. By zaspokoić swoją ciekawość, udaje się specjalnie do Konsula RP w Irkucku, który wyjaśnia i rozwiewa wszelkie wątpliwości autora (PB, s. 12-13). Podróżnik uznaje, że by poznać dobrze kulturę i zwyczaje mieszkańców Irkucka, których określa mianem „tubylców”, powinien się do nich upodobnić. W związku z tym decyduje się na wizytę u fryzjera. Na miejscu oczywiście odkrywa polskie akcenty - w radiu słyszy piosenkę Maryli Rodowicz, a babcia fryzjerki okazała się Polką. „Polscy przodkowie to raczej reguła niż wyjątek" - konstatuje i kilkakrotnie na kartach książki podkreśla, że spotkani bohaterowie mają polskich przodków (np. naczelniczka bazy turystycznej nad Bajkałem). Rybicki znajduje się więc w mieście, które w pewnym stopniu można uznać za „swoje”, ponieważ wcześniej zostało skolonizowane przez Polaków. Za chwilę dodaje:

Polacy odegrali w dziejach Irkucka kluczową rolę. Według relacji samych Rosjan, w drugiej połowie XIX wieku miejscowy handel był wręcz zdominowany przez zesłańców. Kiedy w 1883 roku, po amnestyjnym manifeście cara Aleksandra III wielu Polaków zdecydowało się opuścić Syberię, irkucka gazeta "Sibir” w artykule Poljaki w Sibirii pisała z żalem: „Bardzo wiele przyczynili się do rozwoju rzemiosła i ogrodnictwa w Syberii [...]. Przedtem nie było w Syberii ani restauracji, ani kawiarni, ani porządnych hotelów. Do obyczajów i stosunków narodu i społeczeństwa sybirskiego [...] wnieśli Polacy — zesłańcy polityczni niektóre swe narodowe sympatyczne przymioty, jako to grzeczność, wstrzemięźliwość, takt i nadzwyczaj ludzkie, od razu się w oczy rzucające, obchodzenie się ze służącymi. Polacy bez wątpienia przyczynili się do podniesienia poziomu umysłowego" (PB, s. 16-17).

Cytaty przytaczane przez Rybickiego to kolejne dowody na wyższość Polaków.

Rola Polaków, ich dokonania w Rosji są podkreślane w książce kilkakrotnie. Podróżnik opowiada o Polakach - najlepszych fachowcach, budujących kolej transsyberyjską (PB, s. 349), o historii Jana Czerskiego (PB, s. 217-219), o podróży Kazimierza Nowaka, który rowerem przejechał przez Afrykę (PB, s. 233-234), czy też o miłości księcia Konstantego - hrabinie Joannie Grudzińskiej, przez którą książę nie został carem (PB, s. 79). Znaczący jest również przedostatni rozdział, zatytułowany Polacy nad Bajkałem, 
w całości poświęcony dokonaniom Polaków w Rosji, w tym m.in. powstaniu zabajkalskiemu i pobytowi Józefa Piłsudskiego w Tunce (PB, s. 363-375).

W relacji z bajkalskiej podróży nie brakuje również wątków dotyczących krytyki Polaków. Rybicki wspomina o barku solidarności między Polakami a Rosjanami, którzy wspólnie trafiali na zesłanie. Wówczas pojawiały się krytyczne głosy na temat powstania listopadowego, określanego przez Rosjan „zdradą warszawską”. Podróżnik pisze także o Dostojewskim, który razem z Polakami przebywał w Omsku: „W poglądach Dostojewskiego zarówno Polska, jak i Ukraina (o Białorusi jeszcze wtedy nikomu nie śniło) były odwiecznymi prowincjami imperium" (PB, s. 83).

Druga część książki, zatytułowana Jezioro, to dziennik rowerowej wyprawy po zamarzniętym Bajkale. Wpisy uporządkowane są według dat. W relacji tej autor momentami zaskakuje czytelnika swoja naiwnością, np. w momencie, kiedy nie przewidział, że skuty lodem Bajkał pokryty jest jeszcze warstwą śniegu, która utrudnia jazdę rowerem. Zadziwia jednak skrupulatność przygotowań do tej wyprawy, m.in. samodzielna produkcja batonów energetycznych (PB, s. 206-207), znajomość statystyk dotyczących Bajkału (PB, s. 131) czy też historia powstania Kolei Bajkalsko-Amurskiej, zwanej BAM (PB, s. 158). Zastanawia również postawa wobec mieszkańców okolic Bajkału: $\mathrm{z}$ jednej strony pełne zainteresowanie, a nawet momentami wścibskość, z drugiej strony niechęć do inności, tak jak w przypadku spotkania $z$ rosyjskim homoseksualistą (PB, s. 329) lub też podejście pragmatyczne, które polega na wykorzystaniu rosyjskiej gościnności do zdobycia ciepłego miejsca na nocleg.

Jakub Rybicki, w przeciwieństwie do Wacława Radziwinowicza, dopuszcza jednak do głosu współczesnych Rosjan, którzy z życzliwością zwracają się do polskich rowerzystów. Wprawdzie tylko jeden Rosjanin (Jura) nie pyta, po co jechać rowerem po Bajkale (PB, s. 75), jednak wszyscy pozostali, napotkani po drodze „tubylcy" nie wydają się uprzedzeni. Zresztą odpowiedź na to nurtujące mieszkańców okolic Bajkału pytanie pada dopiero w ostatniej części książki: „Po co pojechałem na Bajkał? Żeby wyzwolić się z krępujących reguł społeczeństwa, odpocząć od norm Unii Europej- 
skiej i bezpiecznej nudy żywota drobnomieszczanina" (PB, s. 342). Rybicki przeciwstawia tym samym Rosję Europie, pisząc dalej, że w Rosji nie obowiązują abstrakcyjne zakazy. „W tej krainie każdy sam tworzy własne zasady, negocjując je z okolicznymi duchami, tajgą, niedźwiedziami, policją, urzędnikami i starikiem Bajkałem" (PB, s. 342). Pobrzmiewają tu echa Saidowskiego orientalizmu systemu stworzonego na dychotomii „my”, czyli Zachód, versus „oni”, czyli Wschód. Opozycja ta pozwala na określenie swojej tożsamości grupy, do której należymy. Oczywiście to rozróżnienie pociąga za sobą przypisanie tym dwóm tworom opozycyjnych cech. Zachód to racjonalność, logika, empiryzm, kultura, realizm. Wschód natomiast - irracjonalność, nielogiczność, zapóźnienie i despotyzmem ${ }^{21}$.

Niezaprzeczalnie atutem książki Jakuba Rybickiego jest zwrócenie uwagi na peryferia Moskwy - małe miasta położone wokół Bajkału, np. Nowoselengińsk (PB, s. 73), Niżnieangarsk (PB, s. 153), Kiachtę, zwaną kiedyś „,małym Petersburgiem” (PB, s. 102), czy też Chużyr na wyspie Olchon (PB, s. 281) - ich mieszkańców i historię. Ponadto autor wzbogaca swoje historie o zdjęcia, które mogą stanowić dla czytelnika przeciwwagę dla opisywanych przez autora miejsc i ludzi. Dzięki nim czytelnik jest w stanie samodzielnie skonfrontować tekst z obrazem. Oczywiście, jest to konfrontacja zapośredniczona przez samego Rybickiego, ponieważ on jest również autorem zdjęć, jednak taki zabieg sprawia, że czytelnik czuje, iż sam może sprawdzić prawdziwość słów.

\section{SŁOWNIK PRAWDĘ POWIE}

Ostatnią perspektywą, którą można wyróżnić wśród najnowszych polskich publikacji podróżniczo-reporterskich o Rosji jest perspektywa osiedleńca. Protoplastą takiego spojrzenia na tę rzeczywistość był Mariusz Wilk, który zdecydował się zamieszkać w Rosji na Sołowkach, później nad jeziorem Onega. Swoje życie, perypetie i ludzi, których poznał, opisał w cyklu książek temu po-

\footnotetext{
${ }^{21}$ M. Janion, Niesamowita Stowiańszczyzna..., s. 224.
} 
święconych. Mimo że sam Wilk wyprowadził się już z Rosji, znalazł swoich naśladowców. Michał Książek, ornitolog, kulturoznawca i reporter, a także syberyjski przewodnik, w 2013 roku opublikował książkę Jakuck: słownik miejsca ${ }^{22}$. Książka stanowi przykład kontynuacji perspektywy opisu Rosji i Rosjan, zapoczątkowanego przez Mariusza Wilka.

Michał Książek w swojej opowieści kroczy śladami dwóch Polaków zesłanych na Syberię. Pierwszym z nich jest Edward Piekarski, lingwista, który w 1888 roku trafił do Jakucka. W czasie swojego pobytu tam opracował Słownik języka jakuckiego. Jest również autorem książki o jakuckiej literaturze. Jak podkreśla reporter, postać ta jest bardziej znana w Jakucji niż w Polsce. Za jego zasługi uhonorowano Piekarskiego pomnikiem, który stoi w Jakucku. Drugim patronem opowieści Książka jest Wacław Sieroszewski - pisarz, etnograf i podróżnik, bardziej znany w Polsce niż Piekarski. Sieroszewski trafił na Syberię w 1878 roku po buncie w warszawskiej Cytadeli, a do samego Jakucka przyjechał w 1880 roku. Sławę przyniosła mu książka Dwanaście lat $w$ kraju Jakutów, która stała się podstawową lekturą etnografów zajmujących się Syberią.

Polski reportażysta nieprzypadkowo wybiera obie te postacie. To modelowe historie Polaków, którzy trafili na Syberię. Mimo że pobyt ten był dla nich wygnaniem, zakochali się w kraju i ludziach, odnieśli sukces, a przy okazji wzbogacili swoją działalnością rosyjską kulturę. Tą samą drogą podąża Polak w XXI wieku. Różnica polega jednak na tym, że nie jedzie do Rosji z wyrokiem, lecz samodzielnie wybiera miejsce swojej podróży. Czego szuka Książek? Artykułuje to bardzo wyraźnie - szuka śladów: „Śladów, nie tropów. Śladami myśliwi nazywają oznaki działalności zwierzęcia czy człowieka, tropami zaś same odbicia stóp, łap i kopyt" (JSM, s. 58). Jest to więc podróż śladami sukcesów Polaków, którzy żyli na Syberii. Nie zakłada ona niestety poznania Jakucji i jej mieszkańców bez wcześniejszych uprzedzeń. Książka kulturoznawcy jest zdominowana przez poszukiwanie polskich śladów na Syberii.

\footnotetext{
${ }^{22}$ M. Książek, Jakuck: słownik miejsca, Wydawnictwo Czarne, Wołowiec 2013. Cytaty lokalizuję w tekście za tym wydaniem, podając w nawiasie skrót KSM i numer strony.
} 
Jako dowód wkładu Polaków w życie rosyjskiej społeczności już na pierwszych stronach książki pojawiają się inni polscy bohaterowie. Książek przytacza nieznaną Rosjanom historię:

Jakucję zdobywał dla cara Polak Antoni Dobryński. Działał na polecenie innego Polaka - Samsona Nowackiego. To Dobryński zbudował pierwszy umocniony punkt na ziemi Jakutów, który jednak z racji małych rozmiarów i krótkiego żywota nie został uznany za początek Jakucka. Nowacki i Dobryński byli jeńcami wojennymi, którzy nie skorzystali bądź nie mogli skorzystać z możliwości powrotu do ojczyzny i służyli pierwszemu Romanowowi (JSM, s. 24).

Informacje w podobnym tonie pojawiają się jeszcze w kilku momentach narracji Książka. Wspomina również o zainteresowaniu carskich władz działalnością Polaków w Jakucji (JSM, s. 135). Bez działań i dowodzenia Polaka, Bolesława Gellerta, w Jakucku nie doszłoby do rewolucji w 1918 roku (JSM, s. 136). Kulturoznawca, podobnie jak inni autorzy książek o Rosji, wywyższa Polaków na polu nie tylko naukowym, lecz także organizacyjnym.

Trzeba jednak zaznaczyć, że ze wszystkich przedstawionych narracji, relacja Książka zawiera najmniej stereotypowych opisów Rosjan. Autor buduje mapę syberyjskiego miasta, które dla polskiego czytelnika jest odległe i trudno dostępne. $\mathrm{Na}$ tę narrację nakłada swoje historie, które porządkuje w dwanaście części słownika języka jakuckiego. W kontekście pozostałych, powstałych po 1989 roku polskich publikacji dotyczących Rosji, jest to pomysł oryginalny. Nie jest to bowiem słownik podobny do tego, który zaproponował Mariusz Wilk. W Wilczym notesie mieszkaniec Sołowek konstruuje na końcu książki słowniczek, z takimi terminami jak kartoszka, bania, bomż czy mużik ${ }^{23}$. Książek proponuje zupełnie inny słownik. Przede wszystkim leksykon ten nie jest dodatkiem do opowieści polskiego mieszkańca Syberii. Cała książka jest słownikiem, o czym sugeruje już jej budowa i sam tytuł. O swojej motywacji stworzenia takiej pozycji autor pisze: „[...] są słowa, które powinien znać każdy, kto chce w Jakucku spędzić zimę. Albo zamieszkać tu na dłużej. Ale nie ma słownika, w którym można je wszystkie znaleźć" (JSM, s. 17).

${ }^{23}$ M. Wilk, Wilczy notes, Noir sur Blanc, Warszawa 2012, s. 193-212. 
Pierwszym hasłem jest słowo balaghan, które oznacza dom lub myśliwski szałas. Wstępem do wprowadzenia tego terminu jest opis położenia mieszkania samego autora, który w kontekście badań postzależnościowych jest znaczący.

Nasze miejsce w Jakucku leży wysoko: na ósmym piętrze nowego wieżowca przy ulicy Lermontowa. Okna małego pokoju wychodzą na wschód. [...] Okna kuchni i dużego pokoju wyglądają na zachód i jak na razie można oglądać z nich plac zabaw w dole, a u góry łańcuch wzgórz i niebo (JSM, s. 15-16).

Mimo że reporter uważa się za mieszkańca Jakucka i z tej perspektywy opisuje otaczającą go przestrzeń, w jego narracjach pojawia się dychotomia: my-oni, nasz-wasz. Jest ona spotęgowana również miejscem, w którym mieszka - wyobcowanym mieszkaniem na jednym z wyższych pięter bloku, ponad innymi zabudowaniami miasta. To kolejny moment, w którym mamy do czynienia w metaforycznie rozumianą wyższością wobec opisywanej rzeczywistości. Jakuck jest jednak książką przewrotną. W kilku częściach słownika Książek zapomina o swojej misji odnalezienia śladów Sieroszewskiego i przedstawia Syberię w sposób do tej pory niespotykany. Mimo że metaforą całej jakuckiej rzeczywistości jest zimna i związana z nią ciemność (co również można uznać za trop badań postzależnościowych), pojawiają się $\mathrm{w}$ książce fragmenty nowatorskie. Warto w tym miejscu wrócić jeszcze do koncepcji słownika. Słownikowe części są urozmaicone rosyjskimi źródłami literackimi. Książek powołuje się na etnografów, lingwistów i pisarzy (na końcu książki dołącza również bibliografię). Ponadto niemalże na każdej stronie Książek zapoznaje czytelnika z nowym hasłem, nieznanym terminem. Kieruje się przy tym zasadą, wedle której tylko przez język możemy poznać nową rzeczywistość i jej mieszkańców:

Jakuckie słowa porządkujące krajobraz plączą się po głowie jak siano we włosach po drzemce w stogu na podmiejskich łąkach. Jakby ich znajomość mogła ustrzec przed zbłądzeniem w rozległym kraju i pozwoliła czuć się bezpieczniej. A miejscowy język miał być panaceum na pierwsze objawy lekkiej agorafobii (JSM, s. 45).

Klamrą kompozycyjną całej książki jest mapa. Jest to klamra dosłowna i metaforyczna. Na pierwszych i na ostatnich stronach 
znajdują się mapy Republiki Sachy i Jakucka. Co więcej, pierwszy i przedostatni rozdział książki noszą tytuł Mapa. Pierwsza część jest wprowadzeniem: „Centralna Jakucja, czyli międzyrzecza Wiluja, Leny i Ałdanu, wygląda na mapie jak manowce na końcu świata”. Stopniowo czytelnik zapoznawany $\mathrm{z}$ meandrami historycznymi tej części Syberii, $\mathrm{z}$ historią powstania Jakucka i historią polskich zasług. Na ostatnich stronach książki przyjmuje natomiast perspektywę odwrotną - wyprowadza czytelnik z Jakucji i sugeruje, by po kursie języka, wyruszyć w dalszą wędrówkę. Ostatnie hasło w słowniku to słowo olootoo, co oznacza 'patrzeć w dal': „Pytam N., czy patrząc na mapę, też mogę powiedzieć olootuubu? Mówi, że jak najbardziej" (JSM, s. 237).

Michał Książek, podobnie jak Mariusz Wilk, w Jakuckiej rzeczywistości jest osadnikiem. Autorowi jednak nie udaje się uciec od postawy byłego skolonizowanego, przekonanego o wyższości swojej kultury nad inną (co widoczne jest w historiach o Polakach na Syberii). Książek kontynuuje zapoczątkowany przez Wilka koncept poszukiwania nowego sposobu opisu Rosyjskiej rzeczywistości, na który zwróciła szczególna uwagę Maria Janion ${ }^{24}$. W syberyjskim przewodniku robi to jednak inaczej. Nie wplata rosyjskich słów w tekst główny, nie spolszcza ich, nie upraszcza. Buduje słownik, który ma ułatwić porozumienie, czyli otworzyć polskiego czytelnika na komunikację.

\section{INTERPRETACYJNA „ZEMSTA”}

Narracje o Rosji i Rosjanach w polskich publikacjach podróżniczo-reporterskich są z jednej strony twórcze, z drugiej jednak niebezpieczne. Ich twórczość polega bowiem na tym, że są to historie nie o Rosji, a o polskim sposobie postrzegania tej przestrzeni i jej mieszkańców. Z tego puntu widzenia są to historie o nas samych, o tym, jak Polacy patrzą na przestrzeń byłego imperium, jakim językiem ją opisują i za pomocą jakich narzędzi. Druga strona medalu pokazuje jednak, jak silna jest narracja ofiary i jakie są jej skutki, nawet gdy sytuacja zależności zanika.

\footnotetext{
${ }^{24}$ Zob. M. Janion, Niesamowita Słowiańszczyzna..., s. 241.
} 
Właśnie Obcy obnaża niespójność świata, w którym znalazł się jako Obcy i to zarówno aksjologiczną, epistemologiczną, jak i ontologiczną, wskazując, iż często nie sprawdzają się w owym świecie kategorie ze sfery podstawowych ludzkich doświadczeń. Obcego nie da się poznać, pojąć, stosując 'nasze' reguły poznawania, rozumienia, bowiem to one definiują go właśnie jako Innego/ Obcego $^{25}$.

Polskie „dialogi” z Rosją i Rosjanami są więc opowieściami o polskim sposobie postrzegania i o zmianie, która w nim zachodzi. Wydaje się bowiem, że narracje omawianych autorów są znacznie bardziej stonowane niż te, które prezentowali Mariusz Wilk, Krystyna Kurczab-Redlich i Jacek Hugo-Bader niespełna kilka lat temu. Kontynuują niestety pewne elementy opowieści poprzedników. W najnowszych książkach wciąż sprawdza się mechanizm, w którym były opresjonowany rozprawia się z byłym opresorem $\mathrm{w}$ narracjach kompensacyjnych, przedstawiając go jako pokonanego. Wacław Radziwinowicz ironicznie podkreśla, że Europa (czyli również Polska) pokonuje Rosję na płaszczyźnie politycznej i kulturowej. Drwi z systemu politycznego Rosji i wszystkich elementów z nim związanych (prezydenta, deputowanych, Dumy, mediów). Z kolei Jakub Rybicki pokazuje, w jaki sposób Rosjanie przegrywają z przyrodą, nieumiejętnie, bez zrozumienia ją wykorzystują, nie doceniają zasobów naturalnych. Jakucja Michała Książka to natomiast kraj, który nie powstałby, gdyby nie działalność polskich emigrantów na polu politycznym, społecznym i kulturowym. Reporter dokonuje metaforycznej kolonizacji poprzez przywołanie pamięci zasług Polaków dla jakuckiej społeczności. We wszystkich tych narracjach Rosja jest $\mathrm{z}$ jednej strony magiczna i fascynująca, $\mathrm{z}$ drugiej jednak wciąż zacofana i niedemokratyczna.

Pozycja opresjonowanego, z której wypowiadają się polscy reportażyści, jest jednak pozycją znacznie bardziej niebezpieczną niż może się wydawać. Ewa Domańska, cytując Umę Narayan, zauważa, że „[...] uprzywilejowanie epistemologiczne zasadza się na przeświadczeniu, iż jednostki i grupy opresjonowane dzięki doświadczeniu ucisku mają bardziej bezpośrednią, wnikliwą oraz krytyczną wiedzę na temat opresji i jej przyczyn niż osoby, które do

\footnotetext{
${ }^{25}$ H. Gosk, Opowieści „Skolonizowanego/kolonizatora”..., s. 229-230.
} 
tych grup nie należą̇" ${ }^{36}$. Uprzywilejowana poznawczo pozycja ofiary nie jest jej dana, lecz musi zostać wywalczona. Z punktu widzenia tego dyskursu „ofiarą się nie jest, ofiara się staje" ${ }^{\prime 27}$. Dlatego, by zyskać status ofiar, należy być aktywnym i walczącym podmiotem. Polskim reportażystom udaje się pójsść o krok dalej. Ich status ofiary jako podmiotu przez lata zależnego od Rosji został powszechnie uznany (sposób opowiadania o historii Polski, sposób uczenia historii w szkołach itp.). Autorzy książek o Rosji w rewanżu proponują więc interpretacyjną „zemstę". Skutki tego odwetu, paradoksalnie, nie uderzają w byłego opresora, ale w członków tej samej wspólnoty. Reportażyści utrwalają stereotypy o Rosjanach i Rosji, utwierdzają polskiego czytelnika w poczuciu wyższości politycznej, społecznej i kulturowej, zamykają pole do dyskusji o różnicach.

Literacka interpretacyjna „zemsta” to początek zupełnie nowej historii o relacjach między polskimi podróżnikami a przestrzenią Rosji. Te coraz częściej powielane schematy opisu byłego imperium każą zredefiniować pozycję, z której obserwują i opisują Rosję Polacy. Bezmyślne odwzorowywanie którejkolwiek z opisanych przeze mnie perspektyw jest przekraczaniem cienkiej granicy między mszczącą się ofiarą a nowym opresorem - ale to zagadnienie na zupełnie inną opowieść, która coraz śmielej domaga się głosu.

Иоанна Ястжембска

СУЩЕСТВУЕТ ЛИ ВСЕ ЕЩЕ ИНТЕРПРЕТАЦИОННАЯ “МЕСТЬ»? РОССИЯ В ПОЛЬСКОЙ ОЧЕРКОВО-РЕПОРТАЖНОЙ ПРОЗЕ ПОСЛЕДНИХ ЛЕТ

Резюме

Автора настоящей статьи интересует положение и роль польского повествования на тему России в литературе после 1989 года. Он пытается толковать творчество польских авторов очерково-репортажной прозы с помощью научных пособий, которые предоставляет постколониальная теория. Центральное место в его анализах занимает понятие интерпретационной «мести».

\footnotetext{
${ }^{26}$ E. Domańska, O poznawczym uprzywilejowaniu..., s. 26-27.

27 Tamże, s. 25.
} 
Исследуемые писатели разделяются на три группы, т.е. поселенцев (Михал Ксёнжек), реколонизаторов (Вацлав Радзивинович) и путешественников (Якуб Рыбицки). В их произведениях Россия показана, с одной стороны, как место магическое и привлекательное, но, с другой, как страна отсталая и недемократическая. Польские репортеры продолжают высказываться с точки зрения бывшей жертвы.

Joanna Jastrzębska

\section{HAS AN INTERPRETATION “REVENGE” ENDED? RUSSIA IN POLISH TRAVEL LITERATURE SINCE 1989}

\section{Summary}

The essay aims at showing which ways an interpretation of literature can turn towards. A proposed way is based on how to functionalise post-colonial criticism tools for the purpose of today's polish literary studies. The author discusses concept of post-colonial researches connected with polish literature about Russia and Russians. The article presents ways of an interpretation of Russia in polish travel literature after 1989. The author writes about three books, witch are a representation of different perspectives of thinking and writing about Russia. The first way is concerned with polish recolonization of the former USSR. Second is connected with a position of a wanderer, who travel from place to place with no permanent home in Russia. The last way shows thinking about Russian Federation in very innovative way, it is perspective of a settler. All those concepts of seeing and describing Russia is infected by an interpretation "revenge". 